\title{
An evolutionary perspective on marine faunal connections between southernmost South America and Antarctica*
}

\author{
J. ALISTAIR CRAME \\ British Antarctic Survey, Natural Environment Research Council, High Cross, Madingley Road, \\ Cambridge CB3 0ET, U.K.
}

\begin{abstract}
SUMMARY: The origins of present day benthic marine faunas from both the Magellan and Antarctic provinces may lie as far back as the Early Cretaceous (approx. $130 \mathrm{Ma}$ ). This was the time of the first significant marine incursion across the Gondwana supercontinent and isolation of a high-latitude group of continents. It was also the probable time of formation of the temperate, Pacific-margin Weddellian Province, which extended from Patagonia, through Antarctica and New Zealand, to south-eastern Australia. Both palaeontological and phylogenetic evidence suggest that a number of living taxa (i.e. genera and families) from both provinces can be traced back to the Late Cretaceous-earliest Cenozoic interval. At this time there was no discernible gradient in taxonomic diversity from either southernmost South America or Australasia into Antarctica. The long, essentially temperate, Eocene epoch was followed by a period of major change during the ensuing Oligocene. At some time during this interval the Antarctic circum-polar current was fully formed and this led to a vicariant event between the Magellan and Antarctic faunas. However, it is important to stress that the intensification of circumpolar circulation also promoted at least some dispersal between various Subantarctic and Antarctic sites. In all probability, it was as late as the late Miocene (some 10-12 m.y. ago) before an intense pattern of thermal zonation (in both horizontal and vertical senses) was established in the world ocean. This may be the true time of full differentiation between the Magellan and Antarctic provinces. Although certain major groups, such as the bivalve molluses and decapod crustaceans, have obviously declined within Antarctic regions through time, others, such as the bryozoans, echinoderms, amphipods and isopods appear to have flourished. The key to evolutionary success in cold polar waters may be not so much resistance to low temperatures, but the ability to exploit novel habitats and trophic regimes. Rates of speciation are not necessarily lower in cold, polar waters, or rates of extinction higher. The Antarctic fossil record suggests that there is no simple relationship between the onset of glaciation and the extinction of certain key bivalve and decapod groups.
\end{abstract}

Key words: Marine biogeography, palaeontology, phylogenetics, palaeoclimatic history.

RESUMEN: UNA PERSPECTIVA EVOLUTIVA DE LAS CONECXIONES ENTRE LAS FAUNAS MARINAS DE LA PARTE MÁS AUSTRAL DE AMÉRICA DEL SUR Y DE LA ANTÁRTIDA. - El origen de la fauna bentónica actual de ambas provincias, la Magallánica y la Antártica, puede remontarse hasta los principios del Cretácico (aproximadamente $130 \mathrm{Ma}$ ). Esta fue la época de la primera incursión marina significativa a través del supercontinente Gondwana y el aislamiento de un grupo de continentes de altas latitudes. Fue, además, el momento probable de la formación de la Provincia templada del margen pacífico del Weddell, la cual se extendió desde la Patagonia, a través de la Antártida y Nueva Zelanda hasta el sureste de Australia. Evidencias tanto paleontológicas como filogenéticas sugieren que un número de taxones vivientes (géneros y familias) de ambas provincias se pueden trazar hasta el intervalo Cretácico superior- Cenozoico inferior. En este momento no existía un gradiente discernible en la diversidad taxonómica hacia la Antártida ni desde el extremo sur de América del Sur, ni desde Australasia. A la extensa época, esencialmente templada, del Eoceno le siguió un período de cambio mayor durante el Oligoceno. En algún momento durante este intervalo, la corriente circumpolar antártica adquirió su forma definitiva, provocando la separación entre la faunas magallánicas y antárticas. Sin embargo, es importante resaltar que la intensificación de la circulación circumpolar también promovió por lo menos alguna dispersión entre varios sitios subantárticos y antárticos. Con toda probabilidad, el patrón marcado de zonación termal (tanto en sentido horizontal como vertical) en el océano mundial, no se esta-

*Accepted July 21, 1998. 
bleció hasta el Mioceno superior (unos 10-12 millones de años atrás). Éste debe haber sido el verdadero momento de la diferenciación entre las provincias Magallánica y Antártica. Aunque algunos grupos mayores, tales como los moluscos bivalvos y los crustaceos decápodos, disminuyeron claramente en las regiones antárticas a través del tiempo, otros, tales como los briozoarios, equinodermos, anfípodos e isópodos parecen haber florecido. La clave para el éxito evolutivo en aguas polares frías pudo no ser tanto la resistencia a las bajas temperaturas, como la habilidad de explotar hábitats y regímenes tróficos nuevos. Las tasas de especiación no son necesariamente menores en aguas polares frías, ni las tasas de extinción mayores. El registro fósil de la Antártida sugiere que no hay una relación simple entre el inicio de la glaciación y la extinción de ciertos grupos claves de bivalvos y de decápodos.

Palabras clave: Biogeografía marina, paleontología, filogenética, historia paleo-climática.

\section{INTRODUCTION}

Antarctica today stands in splendid isolation, surrounded by some of the deepest and coldest seas in the world. And yet we know that this has not always been the case, and that if you go far enough back in time the southern continents were once positioned much closer together and their climates were considerably warmer. The most obvious of the former connections, that with southernmost South America, is marked by the chain of rugged islands and submarine ridges comprising the Scotia Arc. Indeed it is likely that this archipelago facilitates at least 'sweepstake' dispersal both in to and out of the Antarctic at the present day, and may have done so for considerable periods of time in the past (Knox and Lowry, 1977; Clarke and Crame, 1989).

Nevertheless, the overriding impression is that the progressive isolation of Antarctica has led to a drastic reduction in its plant and animal life. This is certainly so in the terrestrial realm where all but a handful of hardy plants and insects on the continent's margins have been eliminated, but is it also correct for the marine one? A transect south from the Magellan region of southern South America, across the Antarctic Convergence, certainly gives the impression of a sharp demise in key benthic groups such as the fish, decapod crustaceans and bivalve molluscs. However other groups, such as the sponges, bryozoans, echinoderms, ascidians, hydroids, amphipods and isopods, seem to thrive in the Antarctic ocean and it is by no means certain that physical isolation has impeded their evolutionary success (Arntz et al.,1997).

It is the intention of this article to review what is known about the nature of the physical connection between southernmost South America and the Antarctic Peninsula region, and how it affected the evolution of benthic marine faunas. Following an account of the geological development of the region, an assessment of the evolution of southern high-lat- itude marine faunas will be made from both palaeontological and neontological perspectives. Finally, a synthesis of some of the principal palaeoclimatic events which may have influenced various evolutionary processes will be given.

\section{GEOLOGICAL FRAMEWORK}

Initial rifting between eastern and western Gondwana (i.e. the Antarctica-Australia-India block on the one hand, and South America-South Africa on the other) occurred as far back as the Early Jurassic period (208-178 Ma). However, it was not until the earliest Late Jurassic (157 Ma) that actual seafloor spreading occurred between these two regions, as evidenced by the formation of the Mozambique and Somali basins, and, in all probability, the southwestern Weddell Sea too (Lawver et al., 1992; Storey, 1996). Between approximately 157 and 130 Ma the break-up of Gondwana was essentially a two plate problem which led to almost the complete severance of the supercontinent (Fig. 1A). Although the precise nature of marine connections between the proto-Weddell Sea and Mozambique and Somali basins has yet to be established fully, this long, narrow seaway is of considerable palaeobiogeographical significance. By Early Cretaceous times (130 Ma) eastern Gondwana was beginning to be physically isolated in the southern high-latitude regions (Fig. 1A).

Perhaps the most obvious question to ask now is how we know that the supercontinent was not completely split in two at this time by the trans-Gondwana seaway ? In reply, the most honest answer would be that such a situation could not be completely ruled out, but it is probably unlikely. The reason for the element of uncertainty here, and indeed for uncertainty in almost all Gondwana reconstructions, is the physical nature of West Antarctica. Whereas East Antarctica is known to comprise a sin- 
gle very large continental block (or craton), West Antarctica is made up of at least five discrete microcontinental fragments. Relative motion of these components, both to each other and to the East Antarctic craton, almost certainly took place throughout the Late Mesozoic and Cenozoic eras, and it is this phenomenon which makes the reconstructions so uncertain (Fig. 1). The Antarctic Peninsula block is of particular importance since, if some sort of relative motion did not take place between it and the rest of West Antarctica, then substantial overlap occurs between it and southernmost South America in fullscale reconstructions (Storey et al., 1988; Storey, 1996).

We may be fairly certain that three of the West Antarctic microcontinental blocks, Antarctic Peninsula, Thurston Island and Marie Byrd Land, comprised a major part of the Gondwana Pacific margin in Late Jurassic-Early Cretaceous times. There is good geological evidence to show that a more or less continuous magmatic arc along their outer margins marked the site of sustained subduction of Pacific Ocean lithosphere (i.e. seafloor); it would seem that this continued northwards in uninterrupted fashion in to the southernmost Andes (Barker et al., 1991) (Fig. 1A). However, at best, this island arc system would have been a narrow feature (perhaps no more than 400km wide; Barker et al., 1991) and its physical continuity is open to question. There is no doubt that parts of it were heavily forested (Francis, 1991), and that at least from time to time terrestrial vertebrates dispersed along its length (Woodburne and Zinsmeister, 1984; Hooker et al., 1991). Nevertheless, substantial parts of the arc could equally well have been represented by a chain of emergent volcanic islands separated by shallow seas. This is suggested both by the similarity of a number of Early Cretaceous fore- and back-arc benthic marine faunas in the Antarctic Peninsula region (Crame, 1992), and by circumstantial evidence which suggests that the arc may not have been a major terrestrial dispersal route. The vagaries of dispersal by intermittent island-hopping may have been an important reason why placental mammals never dispersed from South America to Australasia (Briggs, 1987).

Rifting between Antarctica and Australia may have begun as early as $125 \mathrm{Ma}$, and it is possible that some form of narrow, shallow seaway existed between the two continents by 100-90 Ma (Lawver et al., 1992). Important tectonic changes occurred along the New Zealand sector of the Gondwana Pacific margin at about $105 \mathrm{Ma}$, and by $84 \mathrm{Ma}$ both
New Zealand and the Campbell Plateau had been separated from Marie Byrd Land by seafloor spreading (Fig. 1). All land connections between New Zealand and Antarctica - Australia were ruptured at this time, but there were still shallow marine links
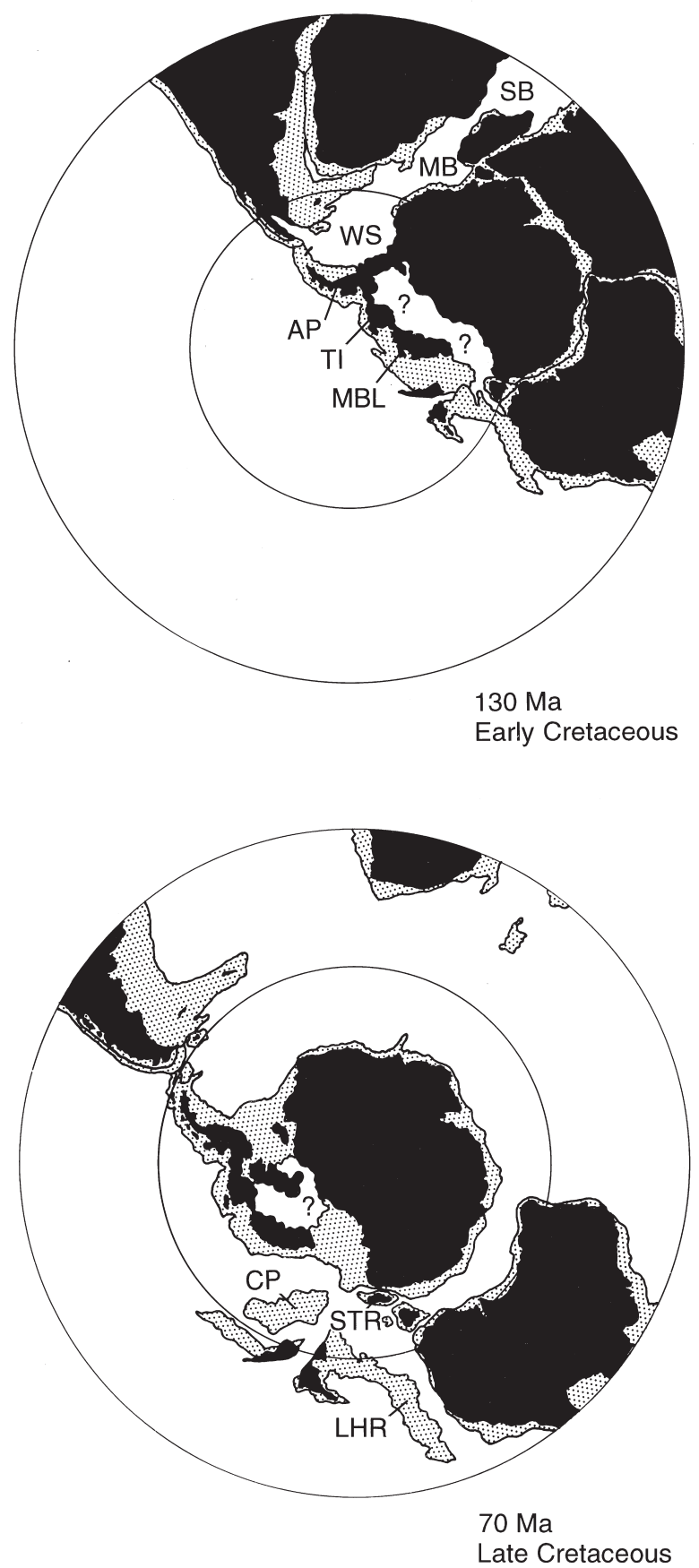

FIG. 1. - Evolution of the Southern Ocean. 1A. Reconstruction of the southern continents at 130Ma. Based on Lawver et al., 1992, Fig. 4. Key: AP - Antarctic Peninsula block ; MB - Mozambique Basin ; MBL - Marie Byrd Land block ; SB - Somali Basin ; TI Thurston Island block; WS - proto-Weddell Sea ; ? - uncertain or oceanic crustal material. 1B. Reconstruction of the southern continents at 70Ma. Based on Lawver et al., 1992, Fig. 10. Key: CP Campbell Plateau ; LHR - Lord Howe Rise; STR - South Tasman Rise. In both $\mathrm{A}$ and $\mathrm{B}$ the circles represent the $30^{\circ}$ and $60^{\circ} \mathrm{S}$ palaeolatitudes, respectively. Continental margins and shelves in stipple. 
for the rest of the Cretaceous period (Stevens, 1989). From approximately 90-70 Ma the gulf between Antarctica and Australia widened considerably, but both Tasmania and the South Tasman Rise formed effective barriers to deepwater circulation. Similarly, the northern tip of the Antarctic Peninsula, and in particular the South Orkneys microcontinent, still blocked the region of the Drake Passage.

Thus as we approach the end of the Cretaceous period (75-65 Ma) the Antarctic continent is still linked, albeit somewhat tenuously, to both southern South America and Australia (Fig. 1B). Nevertheless, it is important to emphasise just how isolated it has now become in the southern high-latitudes, and there is evidence to suggest that even now it may have been subjected to some form of proto-circumAntarctic current. For example, Huber and Watkins (1992, Fig. 21) believe that, by the Late CampanianEarly Maastrichtian (approx. $75 \mathrm{Ma}$ ), shallow marine gateways existed between both the Campbell Plateau and Marie Byrd Land, and South America and Antarctica. Development of the latter may have been aided by both a period of quiescence in volcanic arc activity and a global sea level rise. The rise of this proto-circum-Antarctic current can be linked to both the development of a number of distinct austral lineages and a marked fall in shallow sea surface temperatures (Huber and Watkins, 1992; Ditchfield et al., 1994).

Crucial to the Cenozoic geological history of the Antarctic region is the timing of opening of two key deep ocean gateways: that between East Antarctica and south-easternmost Australia, and that between the southernmost tip of South America and the Antarctic Peninsula (Fig. 1B). For the former of these, there is now geological and geophysical evidence to suggest that the South Tasman Rise (STR) may have been submerged by as early as $64 \mathrm{Ma}$ (i.e. earliest Paleocene). Of course, shallow-marine connections would have persisted in this region, but elsewhere the gap between the two continents may have been as wide as $1000 \mathrm{~km}$ (Veevers et al., 1991; Lawver et al., 1992). Full, deep-water separation of the STR region from Antarctica was probably not achieved until the onset of rapid seafloor spreading at about $50 \mathrm{Ma}$ (i.e. late early Eocene). Whatever was happening in the Drake Passage region at the time (see below), such an event would have been of profound palaeooceanographic significance. By far the greater part of the Antarctic continent was now surrounded by deep-water and it is surely no coincidence that the interval 50-41 Ma saw the com- mencement of the first significant global cooling in the Cenozoic era (Lazarus and Caulet, 1993; see further discussion below). One other important implication of these geological events is that marsupials must have entered Australia by at least 50 Ma, and very probably before $64 \mathrm{Ma}$. Such timing is in broad agreement with molecular phylogenies which suggest that marsupial radiation within Australia is no younger than about $53 \mathrm{Ma}$ (Woodburne and Case, 1996).

Seafloor spreading was producing well-formed magnetic anomalies in the Drake Passage region by $28 \mathrm{Ma}$, and probably began even earlier (Barker et al., 1991; see also, below). Indeed, palaeoceanographic evidence, derived from productivity studies on planktonic forams, suggests a significant marine opening here as early as $36 \mathrm{Ma}$ (Eocene - Oligocene boundary) (Diester-Haas and Zahn, 1996). However, it is important to stress that this was only an opening for surface and intermediate-depth waters.

The prolific land vertebrate fauna from the $\mathrm{La}$ Meseta Formation of Seymour Island (north-easternmost tip of the Antarctic Peninsula) is probably mid-Eocene in age (i.e. approximately 41-37 Ma) (Woodburne and Case, 1996). Nevertheless, taxonomic investigations have revealed elements of both the marsupial and placental mammal components to be highly derived, and they have been linked to progenitors which dispersed from South America into Antarctica in at least the early Eocene (i.e. approximately 54-51 Ma). After that time the respective mammal faunas of these two regions appear to have been separated by some form of vicariant event (Woodburne and Case, 1996).

In summary, it should be stressed that geological events as far back as the Early Cretaceous (i.e. at least some 130 m.y. ago) had a crucial bearing on the evolution of present-day southern high-latitude marine faunas. This is so because it was at this time that a major split occurred across the Gondwana supercontinent, and Antarctica, together with India and Australasia, became significantly isolated for the first time. It was also at this time that a major landbridge was formed, connecting the southern tip of South America with western Antarctica, New Zealand and south-east Australia. However, the geological nature of the Pacific margin of Gondwana casts doubt on its efficacy as a terrestrial dispersal route. Throughout the Late Mesozoic and Early Cenozoic eras it may have facilitated no more than intermittent, or sweepstake, dispersal. By the same token, there may well 
have been at least periodic interchange of shallow marine faunas across this barrier.

The physical isolation of the Antarctic continent was greatly accentuated during the remainder of the Cretaceous period. Just at the time when many key elements in the present-day benthic marine fauna were beginning to evolve (Vermeij, 1977), opportunities for faunal interchange along the continental shelves of the southern high-latitude regions were becoming severely restricted.

\section{EVOLUTION OF SOUTHERN OCEAN MARINE FAUNAS}

\section{Palaeontological evidence}

Later Early Cretaceous (i.e. Aptian - Albian; 124-97 Ma) marine faunas from both the Antarctic Peninsula region and Patagonia have a decidedly temperate aspect (Crame, 1992; Olivero and Martinioni, 1996). Often referred to as "austral", they may be regarded simply as precursors of the betterknown Late Cretaceous-Early Cenozoic Weddellian Province (Zinsmeister, 1982). Characterized by a number of distinctive epifaunal bivalve taxa, these faunas show a distinct lack of any tropical/subtropical (i.e. Tethyan) forms such as rudistid bivalves and nerineid gastropods; they are also of demonstrably lower taxonomic diversity than lower latitude counterparts (Kauffman, 1973). In addition, there is evidence of a strong latitudinal gradient in Albian Southern Hemisphere floras when these are traced northwards from the Antarctic Peninsula into South America and the Falklands Plateau (Dettmann, 1986).

In the latest Cretaceous (i.e. Campanian-Maastrichtian; 83-65 Ma) stages, the Weddellian Province is distinguished by endemic molluscan taxa which include certain cucullaeid and trigoniid bivalves, together with the enigmatic heteroconch genus, Lahillia (Zinsmeister and Macellari, 1988). Endemic gastropods include representatives of the Taiomidae, the subfamily Struthiopterinae (Aporrhaidae) and the entire Family Struthiolariidae. The latter is of particular interest as it is still represented in southern high-latitude regions at the present day: Perissodonta occurs in South Georgia and the Kerguelen Islands, Tylospira in southern Australia, and Pelicaria and Struthiolaria in New Zealand (Zinsmeister and Camacho, 1980). In the Late Cretaceous the Weddellian Province extended from Patagonia, through West Antarctica and New Zealand, to eastern Australia (Zinsmeister, 1982, text-fig. 2).

An indication that some other living Southern Ocean gastropod taxa may have an origin as far back as the Late Cretaceous has been provided by a family-level taxonomic analysis (Crame, 1996, Fig. 10.2). The dominance of certain families at the present day, such as the Naticidae and Buccinidae, can be traced back through late Oligocene-early Miocene and middle-late Eocene intervals into the Campanian-Maastrichtian. The prominence of a third family, the Turridae, can be traced back to the middle-late Eocene. Although this does not, of course, prove a direct line of descent for any living taxon, it suggests that at least some of the dominant groups are of considerable antiquity. Predatory neogastropod families in particular, such as the Buccinidae (sensu lato), Muricidae and Turridae, radiated extensively in the Campanian-Eocene, and there is some evidence to suggest that they did so largely in extra-tropical regions (Taylor et al., 1980; Sohl, 1987).

Although a limited marine fauna is known from the Paleocene Sobral Formation, the next critical fossil horizon within the northern Antarctic Peninsula region is the prolific middle-late Eocene (i.e. approx. 42-33 Ma) La Meseta Formation of Seymour Island. This too, contains distinctive Weddellian elements such as struthiopteran gastropods and lahilliid bivalves, but is particularly noticeable for the number of 'modern' elements that it contains. These include penguins and whales, and, amongst the molluscs, a strong representation of nuculid, nuculanid and limopsid bivalves, and naticid, struthiolariid and buccinid gastropods (Stilwell and Zinsmeister, 1992; Crame, 1996). Living Southern Ocean molluscan genera having their earliest fossil record in the La Meseta Formation include the bivalves Aulacomya, Cyclocardia, Gaimardia and Mysella, and the buccinid gastropod Pareuthria (Stilwell and Zinmeister, 1992). Aulacomya is also known from the late Eocene-early Oligocene San Julian Formation of Patagonia (Beu et al., in press).

As far as can be judged, an Eocene-Oligocene molluscan fauna from Isla Grande, Tierra del Fuego and an Eocene one from the Río Turbio Formation, south-western Patagonia compare well in composition with the La Meseta Formation (Malumian et al., 1978; Griffin, 1991). Of special interest is the record of Laternula sp. from the Río Turbio Formation (Griffin, 1991) as this may be one of the oldest bona fide fossil records of this genus. At the present day, 
Laternula elliptica (King and Broderip) is one of the commonest Antarctic bivalves, but it is only one of some ten species that range collectively from the Southern Ocean to the tropical Indo-West Pacific province. It is quite possible that this distinctive and widespread bivalve genus will prove to be of southern temperate origin.

In summary, it can be stated that, although there are still many gaps in our knowledge, the fossil record is beginning to reveal that the living Southern Ocean molluscan fauna may be of considerable antiquity. A surprising number of elements can now be traced back to the Middle-Late Eocene, and some even further into the Late Cretaceous (Crame,1996). This would not appear to be a young fauna in the early stages of recolonization.

\section{Phylogenetic evidence}

The present day Southern Ocean gastropod fauna (i.e. shelled prosobranchs and heterobranchs) comprises at least 600 species (Crame, 1997). Not only have certain families, such as the Trochidae, Naticidae, Buccinidae, Muricidae and Turridae, diversified considerably within this fauna, but so too have certain genera within these families. Examples here would include Prosipho (Buccinidae), with some 35 species, and Trophon (Muricidae), with approximately 29. Unfortunately, there are as yet no detailed phylogenies for any of these taxa and all that can be said about the timing of their radiations is that they were post-Campanian-Eocene.

Peracarid crustaceans are even more diverse within the Southern Ocean, with there being, for example, some 821 species of amphipods and 408 species of isopods (taking the broad definition of the Southern Ocean used by Crame, 1996, p.119) (Brandt, 1999). Two of the most speciose families of isopods, the Arcturidae and Serolidae, are of particular biogeographical interest as they have recently been shown to be monophyletic (Brandt, 1991, 1992; Wägele, 1994). Within the Arcturidae, the most plesiomorphic taxa are distributed as follows: the Holidotheinae, the most primitive subfamily, occurs only in South Africa; the Pseudidotheinae in Patagonia, South Shetland Islands, Crozet Islands, Kerguelen Island and New Zealand; and the Xenarcturinae in Patagonia only. Similarly, the most primitive serolids were most likely to have arisen along the southern Gondwana margins as they can be shown to be derived from a common ancestor with the Bathynataliidae (South Africa, Australia) and
Plakarthriidae (southern Patagonia, South Georgia, South Orkney Islands, South Shetland Islands and New Zealand) (Brandt, 1999). In both these instances more apomorphic taxa show much wider distributions, with some arcturids reaching the Atlantic and even Arctic oceans, and some serolids moving into the eastern Pacific and along the east coast of South America (Brandt, 1992, 1999).

Other isopod families, such as the Acanthaspidiidae, show essentially similar distributional patterns (Brandt, 1999), as does the major Southern Ocean amphipod family, Iphimediidae (Watling and Thurston, 1989). From all these examples it would seem logical to conclude that the spread of the most primitive taxa around southern Gondwana margins was achieved when the component continents had fragmented, but were still in relatively close juxtaposition. A Late Cretaceous, or perhaps earliest Cenozoic, origin would seem most likely for a number of key Southern Ocean peracarid taxa (Fig. 1B) (Brandt, 1991). Like the gastropods, peracarid clades may be diverse simply because they are old (see discussion section, below).

\section{Evidence from latitudinal diversity gradients}

At the present day there is over $30^{\circ}$ of latitudinal difference between approximately the core region of the Magellan Province and the high Antarctic (i.e. Ronne-Filchner Ice Shelf, Weddell Sea or Ross Ice Shelf, Ross Sea). Moreover this gradient traverses one of the strongest natural boundaries in the world ocean, the Polar Frontal Zone, and it might be expected that some profound biological changes occur along its course. Latitudinal gradients in taxonomic diversity are of particular interest as they are complex phenomena which have almost certainly arisen over long periods of time (Ricklefs, 1987). Their nature and form may yield important clues as to evolutionary processes in high-latitude and polar regions.

Four contrasting types of large-scale latitudinal gradient are illustrated in Figure 2. Demonstrably, for many different groups of plants and animals, there are far more representatives in the low- than the high-latitude regions; the resulting pattern is the familiar bell-shaped curve (Fig. 2A; Huston, 1994, and references therein). To many, such patterns indicate that evolutionary processes are in some way enhanced in the tropics and retarded towards the poles. Perhaps rates of speciation are accelerated in the former region and extinction in the latter (a fuller 
A.

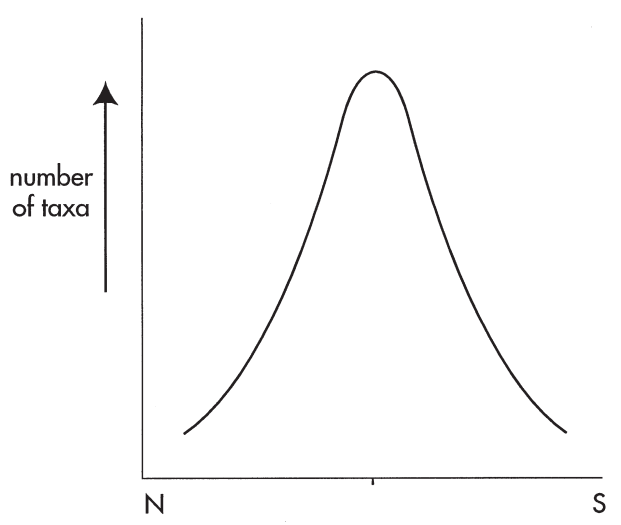

C.

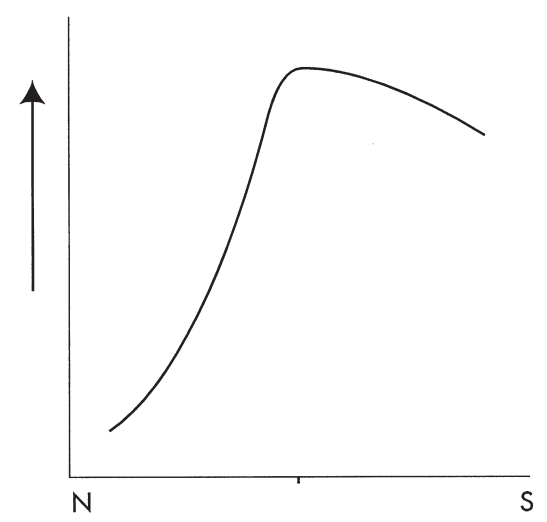

B.

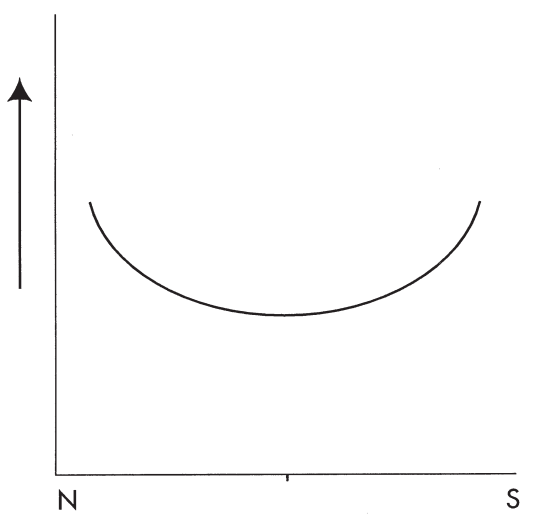

D.

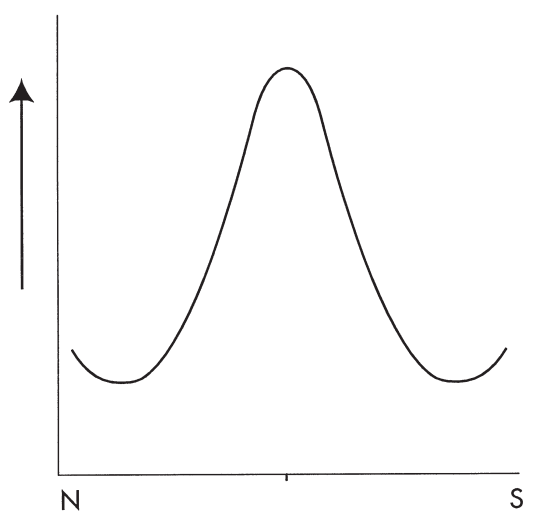

FIG. 2. - Four contrasting types of latitudinal diversity gradient. Abscissa shows North Pole to the left and South Pole to the right. Ordinate shows number of taxa; $\mathrm{N}=$ North Pole, $\mathrm{S}=$ South Pole, and central tick denotes equator.

development of this theme can be found in sources such as Rosenzweig, 1995). Nevertheless, there are some exceptions to this general 'rule' (Huston, 1994, table 2.3), with one important example in the marine realm being provided by coastal- and oceanforaging seabirds. It is likely that these 'reverse' latitudinal gradients (Fig. 2B) are somewhat shallower in nature than their more 'normal' counterparts.

In recent years a volume of evidence has accrued which suggests that there may be a marked asymmetry between latitudinal gradients in the two hemispheres; some groups of plants and animals show much steeper gradients in the northern than southern hemispheres (Fig. 2C; Gaston and Blackburn, 1996; Crame, 1997). The reasons for this phenomenon are not known for certain, but it may be that, for northern hemisphere terrestrial organisms, they have still not recovered fully from the effects of extensive Quaternary glaciations (Gaston and Blackburn, 1996). Higher diversity values for marine organisms in the southern hemisphere may simply reflect the greater area and greater age of the polar ocean (Crame, 1997). Finally, we should be prepared to encounter gradients which are, in some way, hybrids of the previous three. For example, taxa may begin to decrease in taxonomic diversity from low to high latitudes, but then show a marked increase in the polar regions (Fig. 2D; see below).

One of the best examples of a regular decline in taxonomic diversity with increasing latitude (Fig. $2 \mathrm{~A}$ ) is that provided by marine bivalve molluscs. Although the original pattern illustrated by Stehli et al. (1967, Fig. 3) is now known to be in need of some revision, it is in all essential respects still cor- 
rect; whereas the Arctic province contains approximately 199 species and the Antarctic 191, tropical provinces such as the Panamic, Southern China, Philippines, and Queensland-Northern Territory range between 750-1200 species (work in progress by the author). On a smaller scale, a value of approximately 112 bivalve species for the Magellan Province (K. Linse, pers. comm., 1997) can be compared with that of 43 species for the Weddell Sea (Hain, 1990). As planktonic foraminifera show the same regular, monotonic decrease in taxa with increasing latitude (Bé, 1977), it might be assumed that such patterns were a particular property of marine invertebrate organisms possessing a calcareous shell. Perhaps these gradients reflect a latitudinal cline in the nature and rate of calcification (Clarke, 1990). Whilst such a process could indeed be in operation, it has to be borne in mind that diversity patterns within marine gastropods (one of the most diverse of all benthic marine invertebrate groups) are still far from being understood. For example, in a pioneer study of the distribution of predatory prosobranch gastropods on the eastern Atlantic shelf, Taylor and Taylor (1977) found that there was only a decrease in species numbers between equatorial regions and $40^{\circ} \mathrm{N}$. Thereafter diversity rose steadily between $40^{\circ} \mathrm{N}$ and $80^{\circ} \mathrm{N}$, and the overall pattern found was much closer to that in Figure 2D than Figure 2A.

Decapod crustaceans are another group which show a very marked reduction in numbers when traced from southernmost South America into Antarctica; an estimate of 35 benthic decapod species from the Magellan Province can be compared with that of just five benthic species from the continental shelf of the eastern Weddell Sea, although it should be noted that some of these can be abundant (Arntz et al., 1999; Gorny, 1999). Whereas large brachyuran and anomuran crabs are significant components of Patagonian benthic ecosystems (Gorny et al., 1996), the former group is entirely absent from the Scotia Arc and the latter is represented by just two species of lithodids at South Georgia. There is also a record of the stone crab, Lithodes murrayi Henderson, from depths of 180$260 \mathrm{~m}$ at Peter I Island $\left(68^{\circ} 51^{\prime} \mathrm{S}, 90^{\circ} 51^{\prime} \mathrm{W}\right)$ (Klages et al., 1995). Sixteen of the 24 decapod species known from the waters south of Antarctic Convergence are caridean shrimps (Gorny, 1999).

Striking as the bivalve and decapod crustacean gradients may be, they have to be balanced against others which appear to run in the opposite direction. Foremost amongst these is that known to exist for the Bryozoa. Moyano (1996, Table 1), for example, has shown that the total number of bryozoan species (i.e. cheilostomate plus cyclostomate and/or ctenostomate taxa) occurring in the Chilean-Peruvian Province $\left(18-42^{\circ} \mathrm{S}\right)$ is 127 . This figure increases to 205 in the Magellanic Province $\left(42-56^{\circ} \mathrm{S}\right)$ and 225 in the Antarctic Peninsula (see also Zabala et al., 1997). Interestingly enough, the maximum number of species recorded in the southern high latitudes (324) was for the South Island of New Zealand. A number of echinoderm groups too, show similar trends. This is especially true of the ophiuroids, which rise in species numbers from 22 in the Magellan Province to 44 in the Weddell Sea (Dahm, 1999), and the holothurians (Gutt, 1991). Work in progress suggests that sponges comprise another major group to fall into this category (Barthel et al., 1997).

The Magellan-Antarctic region is providing some important new insights into the debate on the nature of latitudinal diversity gradients in the marine realm. This is so because it is clear that, whereas some groups, such as the bivalves and decapods, decrease in diversity into the Antarctic, others, such as the bryozoans and at least some echinoderms, increase. Such a confusion of gradient patterns makes it unlikely that they can be attributed to just one single cause. If, for example, all major taxa showed gradients of decreasing diversity into the Southern Ocean, then it might be hypothesized that this reflected a largescale gradient in productivity patterns. Demonstrably, more of the sun's energy is received in the Earth's low- than high-latitude regions (e.g. Blackburn and Gaston, 1996, and references therein). However, there is then no obvious reason why some taxa should decrease in diversity with decreasing productivity, and others increase; something else must be involved too. Of course, it is important to bear in mind here that we need to know the nature of regional gradients as well as local ones. Is the pattern of diversity increase into high-latitude regions more akin to that shown in Figure 2B or Figure 2D?

\section{A PALAEOCLIMATIC FRAMEWORK FOR EVOLUTIONARY EVENTS}

It is not the intention here to provide a detailed chronology of palaeoclimatic events for the southern South America - Antarctic Peninsula region; reasonably succinct summaries are available in sources such as Clarke and Crame (1992, Fig. 1 and Table 
1), Kennett and Warnke $(1992,1993)$ and Ditchfield et al. (1994). Instead, emphasis will be placed on certain key events which may have been of particular importance in shaping the nature of the benthic marine fauna. Much of this discussion centres on the better-known Cenozoic record.

\section{Opening of Drake Passage}

The precise age of opening of this key oceanic gateway is still open to question. We have already seen that there is evidence of seafloor spreading in the region at $28 \mathrm{Ma}$ (i.e. late Oligocene), but it may have been as late as $23.5 \pm 2.5 \mathrm{Ma}$ (OligoceneMiocene boundary) before a true deep-water connection formed between the South Atlantic and Pacific oceans (Barker et al., 1991, and references therein). We have also suggested that shallowerwater connections existed in the late Eocene (circa $37 \mathrm{Ma}$ ), and perhaps even as far back as the Late Cretaceous (at approximately the Campanian-Maastrichtian stage boundary; $75 \mathrm{Ma}$ ) (see above). The potential for some form of proto-circum-Antarctic current to invoke both climatic cooling and the physical isolation of southern high-latitude marine faunas should not be overlooked.

If it is difficult to pin down the precise time of opening of Drake Passage, then it is equally difficult to determine its exact effects on the marine fauna. Nevertheless, some important clues have been provided by recent advances in our understanding of the evolution of the Notothenioidei, a largely benthic suborder which at the present day completely dominates the Southern Ocean fish fauna. An area cladogram, based on morphological data, shows the Bovichtidae (which occur in Tristan da Cunha, South America, New Zealand and Australia) to be the sister taxon to a clade comprising the five other notothenioid families (which are distributed largely, but not exclusively, in Antarctica) (Eastman, 1993, Fig. 8.1) (Fig. 3A). It would seem logical to place the timing of this split at approximately $55-38 \mathrm{Ma}$, i.e. after the deep-water separation of both New Zealand and Australia from Antarctica. On the other hand, the phylogenetically derived families Artedidraconidae, Bathydraconidae and Channichthyidae are almost exclusively Antarctic in their distribution, and it would be sensible to date their radiation, together with that of at least part of the Harpagiferidae, at after the deep-water opening of Drake Passage (25-22 Ma; Fig. 3A) (Eastman, 1993). Some further comments on the radiation of the

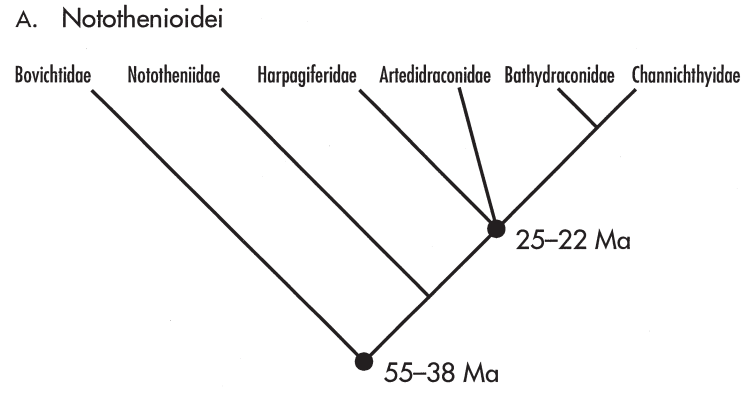

B. Euphausia

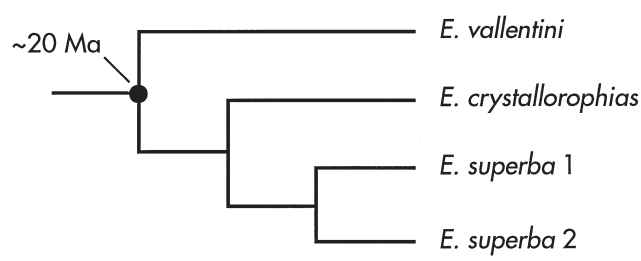

C. Phaeocystis

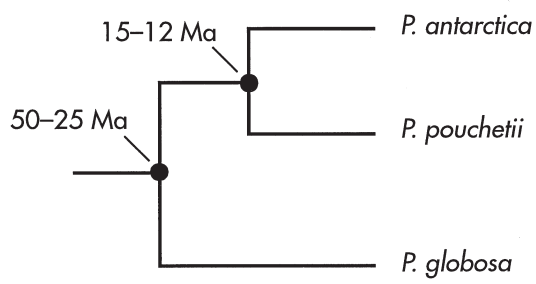

FIG. 3. - Cladistic phylogenies for the Southern Ocean. A. Suborder Notothenioidei. Redrawn from Eastman, 1993, Fig. 8.1. B. Euphausia. Redrawn from Patarnello et al., 1996, Fig. 2b. C. Phaeocystis. Redrawn from Medlin et al., 1994, Fig. 5b. Times of splits between certain sister taxa (in Ma) superimposed on all trees.

notothenioids will be made below.

Using DNA sequence analysis of the 16S rRNA gene and a molecular clock, it has also been possible to date the time of split between Antarctic and subantarctic species within a clade of euphausiid crustaceans (Patarnello et al., 1996). In this study two Antarctic species, Euphausia superba Dana and E. crystallorophias Hold and Tattersall (both collected from the Weddell Sea), were shown to be more closely related to each other than either was to the subantarctic E. vallentini Stebbing (collected from the Straits of Magellan) (Fig. 3B). Using an average divergence rate of $2.5 \%$ per million years, the split between these two sister taxa was dated at approximately $19 \mathrm{Ma}$, whilst an estimate based on distances calculated on transversions only came out at between 19.3 and 20.2 Ma. Patarnello et al. (1996) suggested that these values indicate a vic- 
ariant origin for the split within this clade coincident with the first full formation of the Polar Frontal Zone (which could not have occurred before 25-22 Ma).

In a similar fashion, a molecular study (using the 18S rRNA gene) of the marine alga Phaeocystis has dated an important split between warm- and coldwater taxa as occurring at between 50-25 Ma (and most likely occurred at the younger end of this range, coincident with the opening of Drake Passage; Medlin et al., 1994) (Fig. 3C). Such a vicariant event was followed by the later divergence of two cold-water taxa at $12-15 \mathrm{Ma}$ (the Antarctic $P$. antarctica Karsten, and the Arctic-North Atlantic $P$. pouchetii (Hariot) Lagerheim); this may have been accelerated by dispersal during a global cold phase (Medlin et al., 1994).

The formation of a strong circum-Antarctic current system may also have aided the dispersal of benthic organisms between various southern highlatitude localities. This is particularly so during cold periods (when the current was intensified), and for those organisms with planktonic larval dispersal. Reviewing the Cenozoic molluscan fossil record of southernmost South America and New Zealand, Beu et al. (1997) identified three such times of faunal exchange: (i) an intensive phase of late Oligoceneearly Miocene dispersal, when some 22 molluscan taxa spread from New Zealand to Patagonia, and eight moved in the opposite direction; (ii) a latest Miocene or Pliocene phase of dispersal from Patagonia to New Zealand (9 taxa); and (iii) a Pleistocene phase of dispersal in the same direction which involved at least seven taxa. Included in the latter group are certain tonnoidean gastropods, such as Argobuccinum pustulosum and Fusitriton magellanicus, of north Pacific origin. They indicate the presence of an important trans-tropical dispersal route along the west coast of the Americas (Beu et al., 1977).

Thus it is possible that the opening of Drake Passage and the completion of circum-Antarctic deepwater circulation may have promoted various forms of both vicariance and dispersal. But did these tectonic events really have a profound effect on Southern Ocean palaeotemperatures? It is important to bear in mind here that marine temperatures began to drop in Antarctic and subantarctic regions well before the 30-22 Ma time interval bracketing the opening of Drake Passage. Significant stepwise cooling began in the late Middle Eocene (43 Ma) and at the middle-late Eocene boundary (40 Ma) with approximately $2 \mathrm{C}$ temperature falls (Clarke and Crame, 1992, Fig. 1). These were followed by a major cooling event at the Eocene - Oligocene boundary ( $37 \mathrm{Ma})$ where both surface and bottom waters decreased by as much as $4^{\circ} \mathrm{C}$ in as little as 75-100 k.y. To many observers there is a strong link between the dramatic late Eocene temperature declines and the almost complete physical isolation of the Antarctic continent (Fig. 4A).

Although oxygen isotope palaeotemperature values are difficult to calculate with certainty for the Oligocene epoch, they are generally depicted as relatively constant (Clarke and Crame, 1992, Fig. 1). What is more certain is that a period of global warming occurred in the early Miocene, reaching a Neogene optimum between 19.5-17 Ma. There then followed an abrupt phase of cooling (17-14 Ma) in which both surface- and bottom-water temperatures fell by some $4^{\circ} \mathrm{C}$ (Clarke and Crame, 1992, Fig. 1). It is generally recognised that this was a time of rapid expansion of the East Antarctic ice sheet and associated cooling of Antarctic and subantarctic waters. Quite why the ice cap should expand in this way, some 10-15 m.y. after the completion of the deep-water circumpolar current, is uncertain. Perhaps a prolonged period of increased precipitation during the relatively warm early Miocene was a necessary prerequisite?

It should also be mentioned that other tectonic events were contributing to a mid- to late Miocene fundamental reorganisation of global circulation patterns. Among these were the closure of the Indonesian seaway (by the progressive northward movement of the Australian plate) and the constriction of deep-water flow through the central American seaway. The westward flow of major equatorial surface currents was interrupted and the production of warm, saline bottom waters reduced (Kennett et al., 1985; Woodruff and Savin, 1989). It was during this time interval that polar-equatorial temperature gradients steepened dramatically; Loutit et al. (1983), for example, estimate a Miocene doubling of the Southern Hemisphere gradient from $6^{\circ}$ to $12^{\circ}$ (the latter value being approximately three-quarters of that seen today).

Whatever the precise cause of the middle-late Miocene global cooling event, it is important to recognise that this was a time of major expansion for the Southern Ocean and its glacial marine faunas (Fig. 4B). In addition we also know that, by the late Miocene, latitudinal faunal zones were much more sharply defined in the Southern Hemisphere (Ken- 


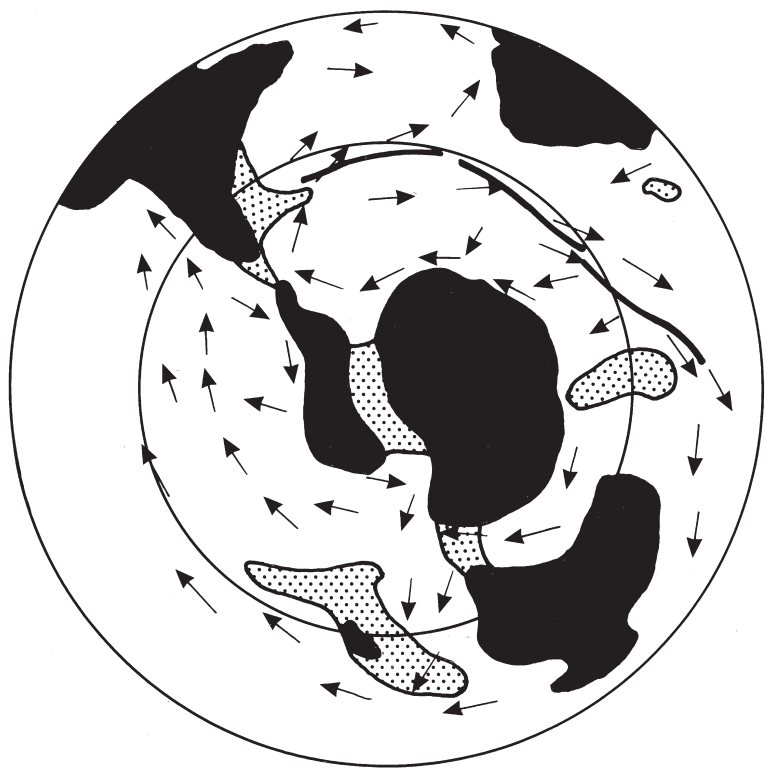

Late Eocene

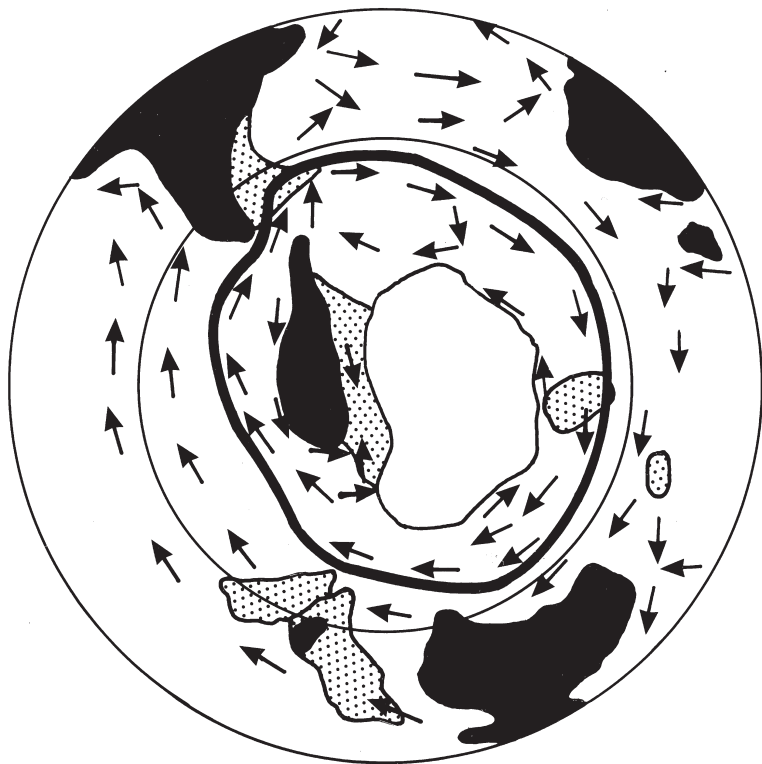

Middle Miocene

FIG. 4. - Development of the circum Antarctic current system. A Late Eocene, and B. Middle Miocene. Redrawn from Lazarus and Caulet, 1993, figs 19 and 22. Proto-polar frontal zone (PFZ) depicted by thin black line in A ; postulated full PFZ shown by heavy black line in B. Strength of arrows proportional to the strength of current flow ; dotted areas represent continental shelf or oceanic crustal material ; East Antarctic ice cap shown in B. Circles represent $30^{\circ}$ and $60^{\circ} \mathrm{S}$ palaeolatitudes, respectively.

nett et al., 1985; Lazarus and Caulet, 1993). Molecular phylogenies, based on $12 \mathrm{~S}$ and $16 \mathrm{~S}$ rRNA genes, suggest that this may well be an alternative time interval for the radiation of the more derived families of notothenioid fish. Divergence times based on a rate of $0.14 \%$ transversion vary from $14-$ $11 \mathrm{Ma}$, but whether standard rates of genomic evolution can be applied to this virtually unique group of fish remains open to question (Bargelloni et al., 1994; Clarke and Johnston, 1996).

\section{Glaciations and the extinction of marine faunas}

We may constrain some of the principal glacial events in Antarctica as follows: the presence of at least some form of ice cap on East Antarctica by the late middle Eocene (43-42 Ma); major expansions of this ice cap at the Eocene-Oligocene boundary (37 Ma) and between the latest early Miocene and middle middle Miocene (17-14 Ma); major development of the West Antarctic ice sheet in the latest Miocene-earliest Pliocene (6.2-4.8 Ma); and onset of bipolar glaciation (2.4 Ma). The question of whether any of these glacial events led directly to extinctions within the marine fauna will be addressed using examples from two benthic groups which are certainly underrepresented in the Antarctic marine fauna at the present day: the decapod crustaceans and the bivalve molluscs.

Decapod crustaceans are well represented in the Late Cretaceous and earliest Cenozoic strata (Sobral Formation) of the northern Antarctic Peninsula region by a wide range of macruran taxa and a single anomuran; both anomurans and brachyurans also occur in the younger (essentially middle-late Eocene) La Meseta Formation (Feldmann and Tshudy, 1989). Thereafter, decapod crustaceans are extremely rare in the Antarctic fossil record and it might, at first sight, be tempting to attribute their demise to the affects of post-late middle Eocene cooling. However, balanced against this conclusion must be the observation that fossiliferous Oligocene-Pliocene strata are rare in Antarctica. A homolodromiid crab is known from the earliest Miocene Cape Melville Formation, King George Island (South Shetland Islands), and a new species of the nephropid lobster Hoploparia has recently been discovered in the same unit (Feldmann and Crame, 1998). In addition, a fragmentary palinurid lobster is also known from the mid-Pliocene of Vestfold Hills, East Antarctica (Feldmann and Quilty, 1997).

It should be pointed out that the early Miocene homolodromiid crab, Antarctidromia inflata Förster, is extremely common throughout the Cape Melville Formation. This is undoubtedly a glaciomarine unit 
and it is apparent that at least this one species was well adapted to cold-water (glacial) conditions. There may be no simple link between temperature decline and the demise of benthic decapods in Antarctica.

At the present day, the pectinid bivalve genus Chlamys, and its close taxonomic allies, is absent from all shallow-water habitats in the Antarctic region. Here, the only common pectinid is one species of the phylogenetically primitive genus Adamussium. The Chlamys group is restricted at the present day to a series of subantarctic sites and it would again appear that some form of temperature control must be the explanation for this distribution pattern (Clarke and Crame, 1989). However, a series of recent discoveries in the fossil record shows just how common the Chlamys group may have been through the Cenozoic era. In chronological order, these are as follows in West Antarctica: La Meseta Formation; Polonez Cove Formation, King George Island (late early Oligocene, $29 \mathrm{Ma}$ ); Hobbs Glacier Formation, James Ross Island group (late Miocene, 6.6 Ma); Cockburn Island Formation, James Ross Island group (late Pliocene, 2.8$2.4 \mathrm{Ma}$ ) (Jonkers, 1998). Further Pliocene and Pleistocene occurrences have also been documented in East Antarctica. Geological evidence shows that some of the associated rock units, such as the Polonez Cove and Hobbs Glacier formations, are at least partly glacial in origin and it is by no means apparent that the Chlamys group is a reliable interglacial indicator. Factors other than temperature may be governing its distribution.

\section{SYNOPSIS}

We must look for the origins of Magellan Province and Antarctic marine faunas as far back as the Cretaceous Period. By approximately $130 \mathrm{Ma}$ (Early Cretaceous), Antarctica, in conjunction with Australasia and India, was beginning to be physically isolated, and by approximately $70 \mathrm{Ma}$ (Late Cretaceous) substantial tracts of the Southern Ocean had formed. Both palaeontological and phylogenetic evidence suggest that a number of key benthic groups in the southern high-latitudes at the present day have Late Cretaceous (i.e. approx 100-65 Ma) origins. As at least some of these groups, such as the gastropod molluscs and peracarid crustaceans, are amongst the richest (in terms of component taxa) in Antarctic and subantarctic regions, there is again evidence of a simple, but fundamental, link between clade age and diversity (Crame, 1997).

By at least the Campanian stage (approx. $83 \mathrm{Ma}$ ), and possibly considerably earlier, a distinctive Weddellian Province can be traced along the Pacific margins of southernmost South America, West Antarctica, New Zealand and south-eastern Australia. This persisted until at least the late Eocene epoch, was of decidedly temperate aspect, and, in all probability, was of lower taxonomic diversity than coeval provinces at lower latitudes. There is no evidence of a particularly steep latitudinal gradient in marine benthic diversity between Patagonia and Antarctica at this time.

If some form of proto-circum-Antarctic current was responsible for the formation of the Weddellian Province, then the inception of the full deep-water current system (at some time during the Oligocene epoch; i.e. approx. 37-23 Ma) was almost certainly responsible for its demise. Both phylogenetic and palaeontological evidence suggests that there was a significant vicariant event at this time across the newly formed Polar Frontal Zone; a Magellan Province could be separated from an Antarctic one for the first time. Nevertheless it is important to stress that it was still some 10-15 m.y. before there was a significant expansion of the East Antarctic ice cap and the cooling of Antarctic and subantarctic waters to values approaching those that we know today. The intense latitudinal zonation of shallow marine faunas seen at the present day may date back no further than the late Miocene epoch (i.e. some 10-12 m.y.). It should be noted that periods of intense circumpolar circulation may also have aided the dispersal of certain types of benthic marine organisms between subantarctic and Antarctic sites. This is especially so for those forms possessing planktonic larvae.

Despite the progressive isolation by cold, deep waters, the Antarctic benthic marine fauna has continued to flourish. Certain important groups, such as the bivalve molluscs and decapod crustaceans, are indeed poorly represented at the present day, but their paucity is counterbalanced by a proliferation of other taxa such as bryozoans, echinoderms, sponges and peracarid crustaceans. There may be no simple link between low temperatures per se and evolutionary success. What may have been more important to the survival and eventual radiation of at least some taxa was the availability of a suitable habitat or food supply. Amongst the most successful benthic marine organisms in the Antarctic at the present day are 
those, such as the bryozoans, sponges, ascidians, gorgonians and hydroids, that are able to build some form of three-dimensional structure and thus feed at more than one level within the water column (Arntz et al., 1994, 1997). Given an oligotrophic but stable regime they have still been able to proliferate. It should also be noted that these organisms have in turn provided a variety of epifaunal habitats for other taxa. Peracarid crustaceans are one group in particular which have proliferated in such habitats (Brandt, 1999).

There is some evidence from the fossil record to show that cold-water marine molluscan clades can radiate just as rapidly as tropical ones (Crame, 1997). If they are less diverse at the present day it is simply because they are younger; the tropical oceans have a far longer geological history than either of the polar ones. It is apparent that there may be no simple link between low temperatures and extinction either. Certain taxa present today in the Magellan region but absent in Antarctica (such as benthic decapods and pectinid bivalves) in fact seem to have considerable Antarctic Cenozoic fossil records. Perhaps they have only just been expelled completely from the Southern Ocean?, or, more likely, they have a long history of fluctuating in concert with constant shifts in the position of the Antarctic Circumpolar Current and Polar Frontal Zone?

\section{ACKNOWLEDGEMENTS}

I would like to thank Wolf Arntz, Angelika Brandt and Carlos Ríos for the invitation to participate in IBMANT 97, and for their hospitality throughout the week. I am also grateful to Wolf Arntz, Angelika Brandt, Andrew Clarke, Rodney Feldmann and Ingo Wehrtmann for comments and suggestions that have improved the manuscript.

\section{REFERENCES}

Arntz, W.E., T. Brey and V.A. Gallardo. - 1994. Antarctic zoobenthos. Mar. Biol. Oceanog. Rev., 32: 241-303.

Arntz, W.E., M. Gorny, R. Soto, M.A. Lardies, M. Retamal and I.S. Wehrtmann. - 1999. Species composition and distribution of decapod crustaceans in the waters off Patagonia and Tierra del Fuego, South America. Sci. Mar., 63(Supl. 1): 303-314.

Arntz, W.E., J. Gutt and M. Klages. - 1997. Antarctic marine biodiversity. In: B. Battaglia, J. Valencia and D.W.H. Walton (eds.): Antarctic communities; species, structure and survival, pp. 3-14. Cambridge University Press, Cambridge.

Bargelloni, L., P.A. Ritchie, T. Patarnello, B. Battaglia, D.M. Lambert and A. Meyer. - 1994. Molecular evolution at subzero temperatures : Mitochondrial and nuclear phylogenies of fishes from Antarctica (suborder Notothenioidei), and the evolution of antifreeze glycopeptides. Mol. Biol. Evol., 11: 854-863.
Barker, P.F., I.W.D. Dalziel and B.C. Storey. - 1991. Tectonic development of the Scotia arc region. In: R.J. Tingey (ed.): The geology of Antarctica, pp.215-248. Clarendon Press, Oxford.

Barthel, D., O.S. Tendal and S. Gatti. - 1997. The sponge fauna of the Weddell Sea and its integration in benthic processes. In: W. Arntz and J. Gutt (eds.): The expedition ANTARKTIS XIII/3 (EASIZ 1) of "Polarstern" to the eastern Weddell Sea in 1996. Ber. Polarforsch., 249: 44-52.

Bé, A.W.H. - 1977. An ecological, zoogeographic and taxonomic review of recent planktonic foraminifera. In: A.T.S. Ramsay (ed.): Oceanic micropalaeontology, Vol.1, pp. 1-88. Academic, San Diego, California.

Beu, A.G., M. Griffin and P.A. Maxwell. - 1999. Opening of Drake Passage gateway and Late Miocene to Pleistocene cooling reflected in Southern Ocean molluscan dispersal: evidence from New Zealand and Argentina. Tectonophysics, 281: 83-97.

Blackburn, T.M. and J. Gaston. - 1996. A sideways look at patterns in species richness, or why there are so few species outside the tropics. Biodiv. Lett., 3: 44-53.

Brandt, A. 1991. Zur Besiedlungsgeschichte des antarktischen Schelfes am Beispiel der Isopoda (Crustacea, Malacostraca). Ber. Polarforsch., 98: 1-240.

Brandt, A. - 1992. Origin of Antarctic Isopoda (Crustacea, Malacostraca). Mar. Biol., 113: 415-423.

Brandt, A. - 1999. On the origin and evolution of Antarctic Peracarida (Crustacea, Malacostraca). Sci. Mar., 63(Supl. 1): 261-274.

Briggs, J.C.- 1987. Biogeography and plate tectonics. Elsevier, Amsterdam

Clarke, A. - 1990. Temperature and evolution : Southern Ocean cooling and the Antarctic marine fauna. In: K. R. Kerry and G. Hempel (eds.): Antarctic ecosystems. Ecological change and conservation, pp. 9-22. Springer-Verlag, Berlin.

Clarke, A. and J.A. Crame. - 1989. The origin of the Southern Ocean marine fauna. In: J.A. Crame (ed.): Origins and evolution of the Antarctic biota, pp. 253-268. Geol. Soc. Lond. Spec. Pub., 47.

Clarke, A. and J.A. Crame. - 1992. The Southern Ocean benthic fauna and climate change: a historical perspective. Phil. Trans. R. Soc. Lond., B 338 : 299-309.

Clarke, A. and I.A. Johnston. - 1996. Evolution and adaptive radiation of Antarctic fishes. TREE, 11(5): 212-218.

Crame, J.A. - 1992. Late Cretaceous palaeoenvironments and biotas: an Antarctic perspective. Antarct. Sci., 4 (4): 371-382.

Crame, J.A. - 1996. Evolution of high-latitude molluscan faunas. In: J.D. Taylor (ed.): Origin and evolutionary radiation of the Mollusca, pp.119-131. Oxford University Press, Oxford.

Crame, J.A. - 1997. An evolutionary framework for the polar regions. J. Biogeogr., 24: 1-9.

Dahm, C. - 1999. Ophiuroids (Echinodermata) of southern Chile and the Antarctic: Taxonomy, biomass, diet and growth of dominant species. Sci. Mar., 63(Supl. 1): 427-432.

Dettmann, M.E. - 1986. Significance of the Cretaceous-Tertiary spore genus Cyatheacidites in tracing the origin and migration of Lophosoria (Filicopsida). Spec. Pap. Palaeont., 35: 63-94.

Diester-Haas, L. and R. Zahn. - 1996. Eocene-Oligocene transition in the Southern Ocean: History of water mass circulation and biological productivity. Geology, 24 (2): 163-166.

Ditchfield, P.W., J.D. Marshall and D. Pirrie. - 1994. High latitude palaeotemperature variation: New data from the Tithonian to Eocene of James Ross Island, Antarctica. Palaeogeogr., Palaeoclimatol., Palaeoecol., 107: 79-101.

Eastman, J.T. - 1993. Antarctic fish biology. Evolution in a unique environment. Academic Press, San Diego.

Feldmann, R.M. and J.A. Crame. - 1998. The significance of a new nephropid lobsters from the Miocene of Antarctica. Palaeontology, 41: 807-814.

Feldmann, R.M. and P.G. Quilty. - 1997. First Pliocene decapod crustacean (Malacostraca : Palinuridae) from the Antarctic. Antarct. Sci., 9: 56-60.

Feldmann, R.M. and D.M. Tshudy. - 1989. Evolutionary pattern in macrurous decapod crustaceans from Cretaceous to Early Cenozoic rocks of the James Ross Island region, Antarctica. In: J.A. Crame (ed.): Origins and evolution of the Antarctic biota, pp. 183-195. Spec. Pub. Geol. Soc. Lond., 47.

Francis, J.E. - 1991. Palaeoclimatic significance of Cretaceousearly Tertiary fossil forests of the Antarctic Peninsula. In: M.R.A. Thomson, J.A. Crame and J.W. Thomson (eds.): Geological evolution of Antarctica, pp.623-627. Cambridge Uni- 
versity Press, Cambridge.

Gaston, K.J. and T.M. Blackburn. - 1996. The tropics as a museum of biological diversity : an analysis of the New World avifauna. Phil. Trans. R. Soc., B 263: 63-68.

Gorny, M. -1999 . On the biogeography and ecology of the Southern Ocean decapod fauna. Sci. Mar., 63(Supl. 1): 367-382.

Gorny, M., W.E. Arntz and R. Soto. - 1996. Crustacean Decapoda: Report on the anomuran and brachyuran crabs. In: W. Arntz and M. Gorny (eds.): Cruise report of the Joint Chilean-German-Italian Magellan "Victor Hensen" Campaign in 1994. Ber. Polarforsch., 190: 60-63.

Griffin, M. - 1991. Eocene bivalves from the Rio Turbio Formation, southwestern Patagonia (Argentina). J. Paleont., 65 (1): 119-146.

Gutt, J. - 1991. On the distribution and ecology of holothurians in the Weddell Sea (Antarctica). Polar Biol., 11: 145-155.

Hain, S. - 1990. Die beschalten benthischen Mollusken (Gastropoda und Bivalvia) des Weddellmeeres, Antarktis. Ber. Polarforsch., 70: 1-184.

Hooker, J.J., A.C. Milner and S.E.K. Sequeira. - 1991. An ornithopod dinosaur from the Late Cretaceous of West Antarctica. Antarct. Sci., 3: 331-332.

Huber, B. T. and D.K. Watkins. - 1992. Biogeography of Campanian-Maastrichtian calcareous plankton in the region of the Southern Ocean : Palegeographic and paleoclimatic implications. In: J. P. Kennett and D. A. Warnke (eds.): The Antarctic paleoenvironment : A perspective on global change. Part One., pp. 31-60. Ant. Res. Ser., 56.

Huston, M.A. - 1994. Biological diversity : The coexistence of species on changing landscapes. Cambridge University Press, Cambridge.

Jonkers, H.A. - 1998. The Cockburn Island Formation ; Late Pliocene interglacial sedimentation in the James Ross Basin, northern Antarctic Peninsula. Newsl. Strat. 36: 63-76.

Kauffman, E.G. - 1973. Cretaceous Bivalvia. In: A. Hallam (ed.): Atlas of palaeobiogeography, pp. 353-383. Elsevier, Amsterdam.

Kennett, J.P. and D.A. Warnke (eds.) - 1992. The Antarctic paleoenvironment : Aperspective on global change. Part One. Ant. Res. Ser., 56. American Geophysical Union, Washington, D.C.

Kennett, J.P. and D.A. Warnke (eds.) - 1993. The Antarctic paleoenvironment : A perspective on global change. Part Two. Ant. Res. Ser., 60. American Geophysical Union, Washington, D.C.

Kennett, J.P., G. Keller and M.S. Srinivasan. - 1985. Miocene planktonic foraminiferal biogeography and palaeooceanographic development of the Indo-Pacific region. In: J.P. Kennett (ed.): The Miocene ocean : paleoceanography and biogeography, pp. 197-236. Mem. geol. Soc. Am.: 163.

Klages, M., J. Gutt, A. Starmans and T. Bruns. - 1995. Stone crabs close to the Antarctic continent: Lithodes murrayi Henderson, 1888 (Crustacea ; Decapoda; Anomura) off Peter I Island (6851'S, $90^{\circ} 51^{\prime}$ W) . Polar Biol., 15: 73-75.

Knox, G.A. and J.K. Lowry. - 1977. A comparison between the benthos of the Southern Ocean and the North Polar Ocean with special reference to the amphipods and the Polychaeta. In: M.J. Dunbar (ed.): Polar oceans, pp.423-462. Arctic Institute of North America, Calgary.

Lawver, L.A., L.M. Gahagan and M.F. Coffin. - 1992. The development of paleoseaways around Antarctica. In: J.P. Kennett and D. A. Warnke (eds.): The Antarctic paleoenvironment : A perspective on global change. Part One, pp. 7-30. Ant. Res. Ser., 56.

Lazarus, D. and J.P. Caulet. - 1993. Cenozoic Southern Ocean reconstructions from sedimentologic, radiolarian, and other microfossil data. In: J.P. Kennett and D.A. Warnke (eds.): The Antarctic paleoenvironment : A perspective on global change. Part Two, pp. 145-174. Ant. Res. Ser., 60.

Loutit, T.S., J.P. Kennett and S.M. Savin. - 1983. Miocene equatorial and Southwest Pacific paleooceanography from stable isotope evidence. Mar. Micropaleont., 8: 215-233.

Malumian, N., H.H. Camacho and R. Gorroño. - 1978. Moluscos del Terciario inferior ("Magallanense") de la Isla Grande de Tierra del Fuego (Republica Argentina). Ameghiniana, 15 (34): $265-284$

Medlin, L.K., M. Lange and M.E.M. Baumann. - 1994. Genetic differentiation among three colony-forming species of Phaeocystis: further evidence for the phylogeny of the Prymnesiophyta. Phycologia, 33 (3): 199-212.

Moyano, H.I. - 1996. Holocene bryozoan links between Australia, New Zealand, southern South America, and Antarctica - a pre- liminary evaluation. In: D.P. Gordon, A.M. Smith and J.A. Grant-Mackie (eds.): Bryozoans in space and time, pp.207-219. National Institute of Water and Atmospheric Research Ltd, Wellington, New Zealand.

Olivero, E.B. and D.R. Martinioni - 1996. Late Albian inoceramid bivalves from the Andes of Tierra del Fuego: Age implications for the closure of the Cretaceous marginal basin. J. Paleont., 70 (2): 272-274

Patarnello, T., L. Bergelloni, V. Varotto and B. Battaglia. - 1996. Krill evolution and the Antarctic ocean currents: evidence of vicariant speciation as inferred by molecular data. Mar. Biol., 126: 603-608

Ricklefs, R.E. - 1987. Community diversity: Relative roles of local and regional processes. Science, 235: 167-171.

Rosenzweig, M.L. - 1995. Species diversity in space and time. Oxford University Press, Oxford.

Sohl, N.F. - 1987. Cretaceous gastropods: contrasts between Tethys and the temperate provinces. J. Paleont., 61: 1085-1111.

Stehli, F.G., A.L. McAlester and C.E. Helsley. - 1967. Taxonomy diversity of recent bivalves and some implications for geology. Bull. geol. Soc. Am., 78: 455-466.

Stevens, G.R. - 1989. The nature and timing of biotic links between New Zealand and Antarctica in Mesozoic and Early Cenozoic times. In: J.A. Crame (ed.): Origins and evolution of the Antarctic biota, pp.141-166. Geol. Soc. Lond. Spec. Pub., 47.

Stilwell, J.D. and W.J. Zinsmeister. - 1992. Molluscan systematics and biostratigraphy. Lower Tertiary La Meseta Formation, Seymour Island, Antarctic Peninsula. Ant. Res. Ser. 55: 1-192.

Storey, B.C. - 1996. Microplates and mantle plumes in Antarctica. Terra Ant., 3 (2): 91-102.

Storey, B.C., I.W.D. Dalziel, S.W. Garrett, A.M. Grunow, R.J. Pankhurst and W.R. Vennum. - 1988. West Antarctica in Gondwanaland: Crustal blocks, reconstruction and breakup processes. Tectonphysics, 155: 381-390.

Taylor, J.D. and C.N. Taylor. - 1977. Latitudinal distribution of predatory gastropods on the eastern Atlantic shelf. J. Biogeogr., 4: 73-81.

Taylor, J.D., N.J. Morris and C.N. Taylor. - 1980. Food specialization and the evolution of predatory prosobranch gastropods. Palaeontology, 23: 375-409.

Veevers, J.J., C.M. Powell and S.R. Rotts. - 1991. Review of seafloor spreading around Australia. I, Synthesis of the patterns of spreading. Austr. J. Earth Sci., 38: 373-389.

Vermeij, G.J. - 1977. The Mesozoic marine revolution: evidence from snails, predators and grazers. Paleobiology, 3: 245-258.

Wägele, J.W. - 1994. Notes on Antarctic and South American Serolidae (Crustacea, Isopoda) with remarks on the phylogenetic biogeography and description of new genera. Zool. Jb. Syst., 121: 3-69.

Watling, L. and M. Thurston. - 1989. Antarctica as an evolutionary incubator: evidence from the cladistic biogeography of the amphipod family Iphimediidae. In: J.A. Crame (ed.): Origins and evolution of the Antarctic biota, pp. 297-313. Geol. Soc. Lond. Spec. Pub., 47.

Woodburne, M.O. and J.A. Case. - 1996. Dispersal, vicariance, and Late Cretaceous to Early Tertiary land mammal biogeography from South America to Australia. J. Mamm. Evol., 3 (2): 121-161

Woodburne, M.O. and W.J. Zinsmeister. - 1984. The first land mammal from Antarctica and its biogeographic implications. $J$. Paleont., 58: 913-948.

Woodruff, F. and S.M. Savin. - 1989. Miocene deepwater oceanography. Paleooceanography, 4: 87-140.

Zabala, M., C. Orejas and V. Alvà. - 1997. Bryozoans of the Weddell Sea. In: W. Arntz and J. Gutt (eds.): The expedition ANTARKTIS XIII/3 (EASIZ 1) of "Polarstern" to the eastern Weddell Sea in 1996. Ber. Polarforsch., 249: 55-61.

Zinsmeister, W.J. - 1982. Late Cretaceous-Early Tertiary molluscan biogeography of the southern circum-Pacific. J. Paleont. 56 (1): 84-102.

Zinsmeister, W.J. and H.H. Camacho. - 1980. Revision of the gastropod family Struthiolariidae from Seymour Island, Antarctica. J. Paleont., 54 (1): 1-14.

Zinsmeister, W.J. and C.E. Macellari. - 1988. Bivalvia (Mollusca) from Seymour Island, Antarctic Peninsula. In: R.M. Feldmann and M.O. Woodburne (eds.): Geology and paleontology of Seymour Island, Antarctic Peninsula, pp.253-284. Geol. Soc. Am. Mem.,169. 